\title{
CASE COMPOUNDING IN BESERMAN UDMURT
}

\author{
Timofey Arkhangelskiy ${ }^{1}$ and Maria Usacheva ${ }^{2}$ \\ ${ }^{1}$ Universität Hamburg and ${ }^{2}$ Institute of Linguistics, Russian \\ Academy of Sciences / Pushkin State Russian Language Institute
}

\begin{abstract}
The topic of this paper is case compounding, i.e. attachment of multiple case markers to a noun stem, in Beserman Udmurt, which we also briefly compare to Literary Udmurt. Almost all types of case compounding as described by Noonan (2008) are attested in the language, however derivational compounding and compounding due to suspended affixation only play a marginal role. We use referential communication experiments and corpus data to analyze the constraints on this phenomenon. We also argue that possessive marking, which is often said to be obligatory in compounding (e.g. Alatyrev 1983: 586, Winkler 2001: 43), is in fact triggered by informational-structural factors that are associated with compounding, rather than by compounding itself. The paper is based primarily on the data that we collected in the field in 2003-2017.
\end{abstract}

Keywords: Udmurt, Beserman, case compounding, information structure

DOI: https://doi.org/10.12697/jeful.2018.9.1.05

\section{Introduction}

By case compounding we understand a situation whereby two or more case markers attach to the stem (including cases with null nominative marker, as in (5)), as can be seen in the Beserman example (1). We will refer to the leftmost case suffix as the "inner" case, and to the cases located to the right of it, as the "outer" cases.

(1) s'as'ka-en-ze

flower-INS-POsS.3sG.ACC

'[do something with] the one with a flower'

A typical context in which a form such as (1) could appear, would include several objects, e.g. pots, one of which is decorated with a flower. Such an object can be described by an NP s'as 'ka-en kastr'ul'a flower-INS pot '(a) pot with a flower', where the word for pot is the head. In the syntactic position of direct object, the head may attach 
the accusative marker. However, under certain circumstances, the head may be elided from the NP, which roughly corresponds in meaning to replacing it with 'one' in English. Its accusative marker, however, attaches to its modifier, giving the form with case compounding as a result.

The phenomenon in question was extensively researched in the languages of Australia (see e.g. Dench and Evans 1988, and the papers in Plank 1995). However, it is also quite widespread in other parts of the world. Noonan (2008) provides an overview of case compounding in the Bodic languages (Tibeto-Burman). It also exists in a number of Turkic and Uralic languages, e.g. in Bashkir (Privizentseva, p.c.), Hill Mari (Kozlov and Privizentseva, p.c.) and Mordvin (Hamari 2015, 2016; Privizenceva 2015).

The grammars of the Permic languages (Bubrikh 1949 for Komi, Perevoščikov 1962 for Udmurt) reveal that the phenomenon in question takes place there as well. Alatyrev (1983: 586) in his concise overview of Udmurt grammar considers the most frequent type of case compounding in Udmurt, the simple headless adnominal, which is also represented in (1). Based on examples such as (2) and the implicit presupposition that the $3 \mathrm{sg}$ possessive marker is obligatory in these constructions, he comes to the conclusion that there exists a separate grammatical category ('specifying-indicative category'), whose marker is formally identical to that of POSs.3sG and which is used to transform an adnominal into a noun that can be further inflected.

\author{
(2) a. gurt-len-ez \\ village-GEN-POSs.3sG \\ 'the one that belongs to the village' \\ b. gurt-len-ez-len \\ village-GEN-POSS.3SG-GEN \\ 'of the one that belongs to the village' \\ c. gord-ez \\ red-Poss.3sG \\ 'the red one' \\ d. gord-ez-len \\ red-Poss.3SG-GEN \\ 'of the red one'
}


In Udmurt, this phenomenon can manifest itself in different forms, some of which are different in structure than those in (1) and (2). We are going to use the classification and the terminology provided in Noonan (2008) throughout the paper. The relevant kinds of compounding described there are case stacking, derivational, referential, headed adnominal (with or without case marking on the head), headless adnominal and complex attributive nominal.

We are specifically interested in the data of the Beserman dialect, although we also look briefly into the data from the literary language. Beserman is an unwritten dialect of Udmurt spoken by ethnic Besermans, who live primarily in North-Western Udmurtia. The number of ethnic Besermans, according to the 2010 census, is 2201 ; there are 10 predominantly Beserman villages and 41 villages with mixed population. All Besermans are bilingual in Russian, many are also familiar with standard Udmurt. The dialect differs from the literary language on phonetic, morphosyntactic and lexical levels, however, the two varieties are generally mutually intelligible. In additional to standard Udmurt case inventory, Beserman Udmurt has the recessive case and a series of personal-local cases (Usacheva and Arkhangelskiy 2017); see Appendix 1 for a comparison of Standard Udmurt and Beserman case systems. The Beserman grammar was partly described by Tepljašina (1970) and Ljukina (2008). All Beserman data that we use was collected in the village of Shamardan (Yukamenskoye district, Udmurtia, Russia) in a series of field trips in 2003-2017. The Beserman examples in the paper either come from one of the referential communication experiments conducted in 2015-2016 (see Section 4) or were elicited. The literary Udmurt data comes solely from the Corpus of Standard Udmurt ${ }^{1}$. The following abbreviations are used to mark the source of examples: U - Corpus of Standard Udmurt; B - Beserman oral corpus, including the experimental transcripts; $\mathrm{E}$ - elicited Beserman example.

Although case compounding also happens with pronouns, we will focus only on nouns in this paper for the sake of space.

1 http://udmurt.web-corpora.net 


\section{Types of case compounding in Beserman Udmurt: an overview}

Out of the seven kinds of compounding described in Noonan (2008), we attested the following in Beserman or literary Udmurt:

a. Simple headless adnominal: a noun marked with an adnominal case is further assigned a case intended for the elided head. This kind is by far the most frequent kind of case compounding and is illustrated in (2a).

b. Headed adnominal with a case-marked head. The only difference between this kind and the previous one is that here the head is not elided, so that the case of the head is present on both the head and the adnominal. This construction occurs less frequently; normally, when the head is present, its dependent is not marked with the case of the head. Example (3) illustrates this kind of compounding.

\section{(3) pic'i pi-lâ s'ed jôrc'i-jen-ez-lô}

little boy-DAT black hair-INS-POSS.3SG-DAT

'[he is giving the candies] to the little boy with black hair' (B)

c. Complex attributive nominal. Noonan (2008) defines this type of case compounding as the one with non-adnominal inner case, which requires additional nominalization/ attributivization. In the context of Udmurt, we redefine this type by emphasizing the first part of the definition and lifting the second. That is, what we refer to as the complex atributive nominal type, is basically same as (a), where the inner case is not adnominal, so the whole construction can be interpreted as an ellipsis of a verbal, rather than nominal, head. In Udmurt, such case compounding is possible without preceding nominalization. In example (4), featuring a chain of three case suffixes, the recently grammaticalized recessive case, which indicates the approximate source of motion, is not adnominal, to the best of our knowledge. A noun in the recessive is usually an adjunct in a clause headed by a motion verb, so that the clauses with compounding (4) can be interpreted as instances of ellipsis of the verb 'coming'. 
(4) Bagurt-las'en mašina lâkt-e=no ježgurt-las'en mašina
(village)-RCS car come-PRS.3sG=ADD (village)-RCS car

lâkt-e. Bagurt-las'en-ez-les' šof'or-ze mon

come-PRS.3SG (village)-RCS-POSS.3sG-GEN2 driver-POSs.3sG.ACC I.NOM

tod-is'ko, a ježgurt-las'en-ez-les'-se mon

know-PRS.1SG but (village)-RCS-POSS.3SG-GEN2-POSS.3sG.ACC I.NOM

ug tod-is'kô.

NEG know-PRS.NEG.SG

'Cars were coming from the side of Bagurt and from the side of Yezhgurt. I know the driver of the one from Bagurt, but I do not know the driver of the one from Yezhgurt (lit. the one of the one from Yezhgurt).' (E)

Although it may seem that the possessive marker is playing the role of a nominalizer here, we are going to show that this is not the case. Somewhat more digestible examples of this kind of compounding result from comparative deletion (see Xolodilova 2015: 3).

d. Derivational: the inner case affix forms a kind of an oblique stem, which is required by the outer case marker. This kind of compounding is very marginal in Beserman (see next subsection).

e. Case stacking: several case affixes are combined to express a meaning compositionally combined from the meanings of the individual affixes. This kind exists in Komi varieties, where several spatial cases can be combined to form a complex spatial case. In Literary Udmurt, however, this kind is virtually nonexistent.

We also introduce the kind (f), Case compounding in coordinating construction. This kind of compounding was not listed in Noonan's classification. It happens when a suspended case affix that appears on the right border of a coordinated NP, has to attach to another case affix which is a part of the coordinating construction (see example 22 and Section 5.3).

The first three kinds have similar syntactic structure and a special relationship with the 3 sG possessive suffix, which, as we are going to show, is governed by the information structure. The kinds $(\mathrm{d}-\mathrm{f})$, on the other hand, are much less frequent than $(\mathrm{a}-\mathrm{c})$, have different constraints and generally are peripheral to the grammatical systems. The discussion of these kinds, therefore, will be organized as follows. In Section 3 , we describe in detail the cases $(\mathrm{a}-\mathrm{c})$. Then, in Section 4, we give an overview of our referential communication experiments, discuss the informational-structural factors and argue that it is these factors that are 
responsible for the appearance of POSS.3sG in the cases $(\mathrm{a}-\mathrm{c})$. Finally, in Section 5 , we briefly cover the peripheral cases $(\mathrm{d}-\mathrm{f})$.

\section{Central kinds of case compounding}

The adnominal (headless or with a marked head) and the complex attributive nominal kinds of case compounding are, in terms of productivity and frequency, central to Beserman grammar. They also share informational-structural properties and morphosyntactic constraints.

We concern ourselves primarily with two questions: (a) which cases can, and which cannot, occupy the inner or the outer place under compounding; and (b) what role in the compounding the POSS.3sG marker plays, which, even if not obligatory, is still ubiquitous in compounded forms. Question (b) is important because the POSs.3sG marker is often seen as a nominalizer that makes case compounding possible. Winkler (2001: 43), for instance, says that "by means of Px3Sg declined nouns can be nominalized", and a similar view is held by Alatyrev (1983). We argue against this interpretation in Section 4, where the informationalstructural properties of case compounding are covered. In this section, we confine ourselves to the question (a), while question (b) will be discussed in Section 4.

\subsection{Adnominals and the inner case}

As mentioned earlier, the most widespread kind of compounding is simple headless adnominal, illustrated in (2). It results from the omission of the NP head, whose case marker is then obligatorily transferred to its dependent. As can be seen from (3), the omission of the head is not obligatory for its case marker to appear on the dependent. Nevertheless, in the cases when the head is present, the dependent is often moved to the right (as in (3)), sometimes several words away from the head (as in (5) below). In ordinary NPs where the dependent is not marked with the case of the head, the dependent usually sits immediately to the left of the head, regardless of the kind of the dependent.

(5) A odig-âz marâm-ez 3'ek vâl-ân s'as'ka-en-ez. and one-POSS.3SG HES-POSS.3sG table on-LOC flower-INS-POSS.3sG

'And one thing (saucepan) with flowers is on the table.' (B) 
This example is also a good illustration of something we analyze as compounding with the nominative as the outer case, despite the fact that there is no overt second case in the form s'as'ka-en-ez 'the one with flower(s)'. The reason for this is the following: case suffixes in Udmurt form "blocks" with possessiveness suffixes: the surface form of the case suffix depends on the presence of a possessiveness suffix, and vice versa. The word in question might look like it had a mere combination of an instrumental case marker and 3sG possessiveness marker. However, if the Poss.3sg present in this example formed a block with the instrumental suffix and thus referred to the flower rather than to the sourcepan, it would necessarily have the form -ôz. The fact that it has the form -ez here suggests that it is a part of the outer case-possessiveness block with an empty nominative marker.

There are apparently no restrictions concerning the outer case in compounded forms: just as any case can be assigned to the elided head, the dependent can receive any case from it. Main morphosyntactic constraints on compounding concern the inner case. Any adnominal case suffix can be the inner case in compounded forms regardless of the outer case. Such cases include at least the genitives ${ }^{2}$ and the instrumental. In (6), we illustrate how case compounding usually occurs: under certain circumstances, a nominal NP dependent in an adnominal case can be replaced with a form with case compounding, while the head may stay or be elided.
a. pet'a-len pâni-jez-les'

2 In Beserman, there are two cases with markers -len and -les'/-lâs', which are referred to here as the first genitive (GEN) and the second genitive (GEN2). The primary function of both these cases is marking the dependent in NPs. The second genitive is chosen if the head of the NP is in the accusative, while the first genitive is chosen in all other cases. The second genitive also has a narrow range of independent functions such as marking the material, and is traditionally called Ablative in standard Udmurt. 
It all becomes much more complicated if the inner case is not adnominal, i. e. when we are dealing with the complex attributive nominal kind. As we have seen in the example (4), it is at least sometimes possible to make a compound out of a non-adnominal case form. Apart from the recessive, we have a handful of examples with the terminative (-oz'), the egressive (-is'en) or the dative (-lâ) as the first case. However, these forms were not universally accepted by the speakers, and those who accepted it, did so only reluctantly. We also have a number of examples with the same compounded forms, but different contexts, that the same speakers rejected as ungrammatical. It seems that for a sentence with such a form to be at least marginally acceptable, the elided verb should be easily and uniquely reconstructible. In (4), for example, the only possible verb is lâktânô 'come', which could be very easily deduced by the listener. Such forms do not appear either in the Beserman corpus or in the Standard Udmurt corpus. Therefore, we must admit that, despite these cases can theoretically be used as the inner part of marginally acceptable case compounding forms, normally they are not allowed to do so. This is similar to Moksha, where case compounding is also available for adnominal inner cases (Hamari 2015), and to Hill Mari, where case compounding requires an attributivizer that makes any case form adnominal (Kozlov and Privizentseva, p.c.)

Although non-adnominal forms can not generally serve as a basis for case compounding with verbal ellipsis, some of them can be replaced by adnominal forms with the same meaning. These forms include, on the one hand, the locative, the illative and the elative (in the proper elative sense), and, on the other hand, the caritive.

\subsection{The adnominal elative and the spatial cases}

The elative case in Udmurt has at least two different functions. In one of them, it conveys standard elative semantics (prototypically, movement of the Figure originating in a container-like Ground). The other function is to produce a locative attributive, an adnominal form with the meaning 'located in/at X', as in (7a). Such elative forms can only occur in the attributive position, which is illustrated in (7b).

$$
\begin{aligned}
& \text { a. Azbar-ôs' vedra-je bâgâ-tek. } \\
& \text { yard-ela bucket-POSs.1SG handle-CAR }
\end{aligned}
$$

'My yard bucket (i. e. the one located, currently or habitually, in the yard) has no handle.' (E) 


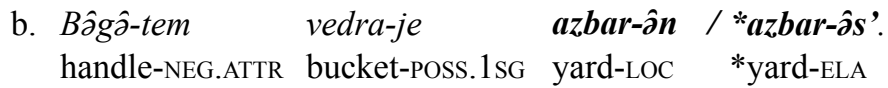

'My handleless bucket is in the yard.' (E)

The elative in this function can thus be perceived as the attributive counterpart of the locative, which can be used only in the predicative position or as an adjunct. It comes as no surprise then that in forms with case compounding where the locative could have been expected, the attributive elative is used instead. It is interesting to note that exactly the same process takes place in Moksha, according to Privizenceva (2015): the locative there cannot become the inner case and is replaced with the elative instead. The situations are not exactly parallel however. In Moksha, the use of the elative in this function outside compounded forms is restricted to topical items, while in focal contexts the locative is used adnominally (Kozlov et al. 2016). In Udmurt, on the contrary, this kind of elative can appear independently without any restrictions, while the locative can never be adnominal. Therefore, this can hardly be treated as a genuine "replacement" of the locative with the elative. What looks more like a replacement is what happens to the illative and the elative proper, which are also not adnominal cases and normally do not participate in compounding as inner cases. Both these cases are replaced with the adnominal elative in forms with compounding. When undergoing this change, the original form retains only a part of its semantics. Consider the following example (8).

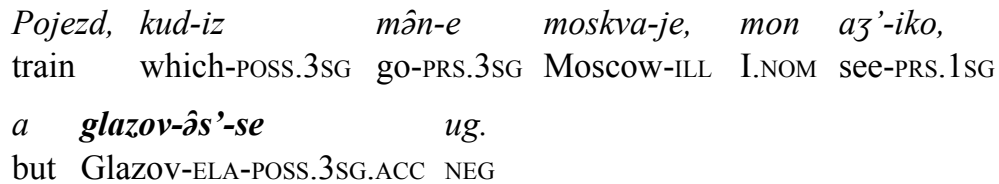

'I see the train that is going to Moscow, but I do not see the one from/to/ in Glazov.' (E)

This sentence has three different readings, the elative, the illative, and the locative (the latter being probably ruled out by the context). An appropriate translation for the form glazovâs'se would be 'the Glazov one': it is clear that the city of Glazov is used as the Ground with the train as the Figure, but the information regarding the orientation of the train is not expressed.

One peculiar thing about the elative in Beserman is that it has two free variants, $-\hat{\partial} s$ ' and -is', in case compounding, while in simple forms 
only - $\hat{s} s^{\prime}$ is grammatical. This does not apply to the standard language, where the only possible elative marker in all contexts is -is'. In many suffixes, literary Udmurt $i$ corresponds to two equally possible variants, $\hat{\partial}$ and $i$, in Beserman (where $\hat{\partial}$ is a direct correspondent for $i$, and $i$ is one of several dialectal features that Beserman shares with the Southern dialects). Unfortunately, we do not have any explanations for this development.

While several speakers admitted the locative as also grammatical in the context "the one [that is located] in Glazov", it was never their first choice when a Russian stimulus was offered, and such compounded forms with the locative as the first case never appeared in the Beserman corpus, with the exception of comparative deletion contexts (see below). Therefore, we can conclude that using the locative as the inner case falls in the same category of marginally possible, but virtually improbable constructions, as the non-adnominal cases discussed above. The standard Udmurt corpus data suggests that the locative/elative relations are largely the same there as in Beserman.

\subsection{The caritive}

The speakers' opinions on whether the caritive (-tek) can become the inner case in compounded forms varies. While some speakers accept such forms, others (or sometimes even the same speakers asked at another time) reject them. It seems that, just as in the case of the locative, the acceptance of those forms depends on whether the speaker can use the caritive form as adnominal. That parallels the situation in Moksha, where the caritive can appear in case compounding and can be used adnominally. The problem with adnominal caritive in Udmurt is that, unlike Moksha, it has a 'real' adnominal counterpart, the negative attributive (-tem), which is the first choice for adnominal use. Both markers can be seen in their typical positions in (7). Unlike the elative, the negative attributive is a derivational, rather than inflectional, suffix which produces an adjective (which can be further inflected with adjective-specific morphology). In case compounding forms, the caritive can always be, and normally is, replaced with the negative attributive, as in (9). 
(9)
Kud-ze
ton
ju-o-d,
which-POSS.3SG.ACC
you(SG).NOM drink-FUT-2SG
tal'inka-en-ze $=w a$
il'i tal'inka-tem-ze $=w a$ ?
saucer-INS-POSS.3SG.ACC $=\mathrm{Q}$ or saucer-NEG.ATTR-POSS.3SG.ACC $=\mathrm{Q}$

'Which one (cup of tea) will you drink, the one with a saucer or the one without a saucer?' (B)

We do not have any examples of case compounding with caritive in our texts. The standalone caritive is almost always used in adverbial or predicative positions. However, attributive usage also occurs a couple of times in texts, despite the fact that some speakers consider such sentences ungrammatical. The speakers who accept these sentences tend also to accept the caritive in case compounding.

When the replacement takes place, it is pretty straightforward. What is not so clear, however, is the following form (10) that was used several utterances later in the same dialogue as (9).
a davaj bl'uda-jen-tem-ze
c'aj-ze
ju
and let's saucer-INS-NEG.ATTR-POSS.3SG.ACC tea-POSS.3sG.ACC drink:IMP

'Why don't you drink the [cup of] tea without a saucer?' (B)

The speakers who we asked about it confirmed that this form with two seemingly opposite markers was grammatical and had no differences in meaning with just bl'uda-tem-ze 'saucer-NEG.ATTRPOSS.3SG.ACC' (without the instrumental). We do not as of now know why such combination is possible.

\subsection{Comparative deletion}

Case compounding which results from the ellipsis of a part of the clause under comparison, known as comparative deletion, is special because it lifts the restrictions described above. Beserman provides two ways of marking the standard of comparison, not counting the frequently used Russian loanword c'em 'than' (Xolodilova 2015). One way involves the postposition $s$ 'arâs' 'about/than', and the other is attaching the second genitive marker to the standard of comparison. When the second strategy is employed and the standard of comparison is already inflected for some case, the first case marker may be retained, which leads to case compounding. Thus, this Beserman comparative 
construction combines the features of fixed-case and derived-case strategies, in terms of Stassen (1985), i.e. consistently marking the standard of comparison with a special case and marking it with the same case as the comparee. Unlike in all other cases, there seem to be no restrictions on the inner case then. Also, the POss.3sG marker usually does not appear in this construction. The same goes for the literary language, which uses the same two comparative constructions. In (11), we see the locative as the inner case in such a construction, where the second occurrence of dun 'price' was elided.

(11) Bakc'a.jemišs-jos-lị dun-jos, pe, magaz'in-inn-les' pic'i=ges. vegetables-PL-DAT price-PL CIT store-LOC-GEN2 small $=$ CPR

'The vegetable prices [at the market] are said to be lower than in the stores.' (U; Udmurt dun'n'e, 14.11.2007)

\section{Information structure and the Poss.3sg marker}

In this section, we explore the informational-structural factors that trigger the appearance of forms with case compounding in speech. We consider here almost exclusively the adnominal case compounding kinds. We reflect on the question of whether and why the Poss.3sG marker is obligatory in such forms, which was posed in Section 3. Based on our observations on the connection between the information structure of an utterance and case compounding, we claim that POSs.3 $3 \mathrm{SG}$ is merely a consequence of the same factors that trigger case compounding, rather than an obligatory nominalizer.

\subsection{Referential communication experiments}

In our 65,000 token corpus of Beserman, we found only three instances of case compounding. Since it is very difficult to study informational-structural factors based only on elicited examples, we designed and ran two experiments that involved quasi-spontaneous communication between speakers in a carefully designed setting. The experiments were carried out in 2015-2016. As a result, we got about 24,500 tokens of transcribed conversations that contained about 70 case compounding examples of different types. 
The experiments were designed according to principles of referential communication tasks method. This method was suggested by Krauss and Weinheimer (1966). It is widely used during experiments with children (O'Neill 1996, Pan and Snow 1999, Girbau 2001) and with deaf people (Zajceva 2000), in teaching foreign languages (Yule 1997), study of syntactic priming (Judina and Fedorova 2009). During referential communication experiments the linguist records the dialogue between speakers who communicate by the phone or through a non-transparent screen. One of the speakers, the Director, receives certain information which they should verbally transfer to their addressee, the Matcher. Fig. 1 shows the setting of one of our experiments.

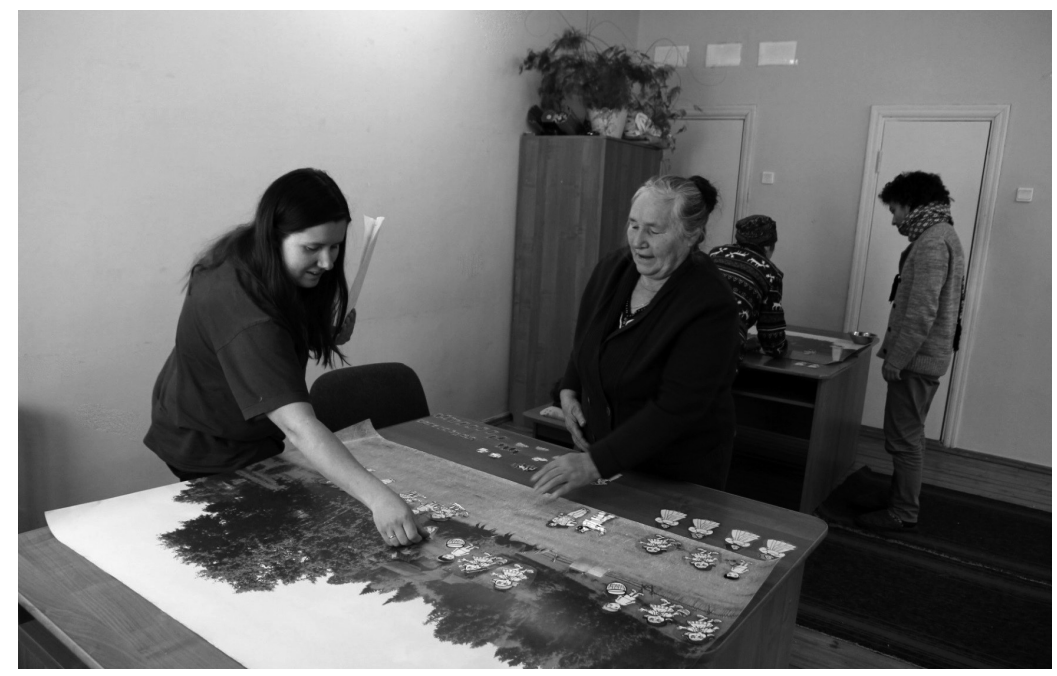

Figure 1. The experimental setting

There are two main types of tasks given to the experiment participants: ordering of objects from a pile and finding the right way in a maze. We ran both types of experiments. During ordering objects from a pile, the linguist puts cards in front of the Director in a fixed order. In 2015, we used a variation of "ordering-objects-from-a-pile" experiments which involved background, a poster-size photo of a location in Shamardan village, where the experiment was conducted. Pictures with figures representing people, animals and other objects, were put on the poster in small portions (three or four cards at a time). After a given set was described by the Director and put by Matcher, the next set came. In this experiment, 32 different types of cards were used in total. 
In 2015, we did not get any examples of case compounding in direct object position. So in 2016 we ran another experiment using a different subtype of "ordering-objects-from-a-pile" design without any background picture. The cards also were put in front of the Director in small sets of three, but the table they were put on did not serve as a point of reference. Fig. 2 provides an example of cards we used during this experiment (pictures of fences made of wood and bricks are fillers):

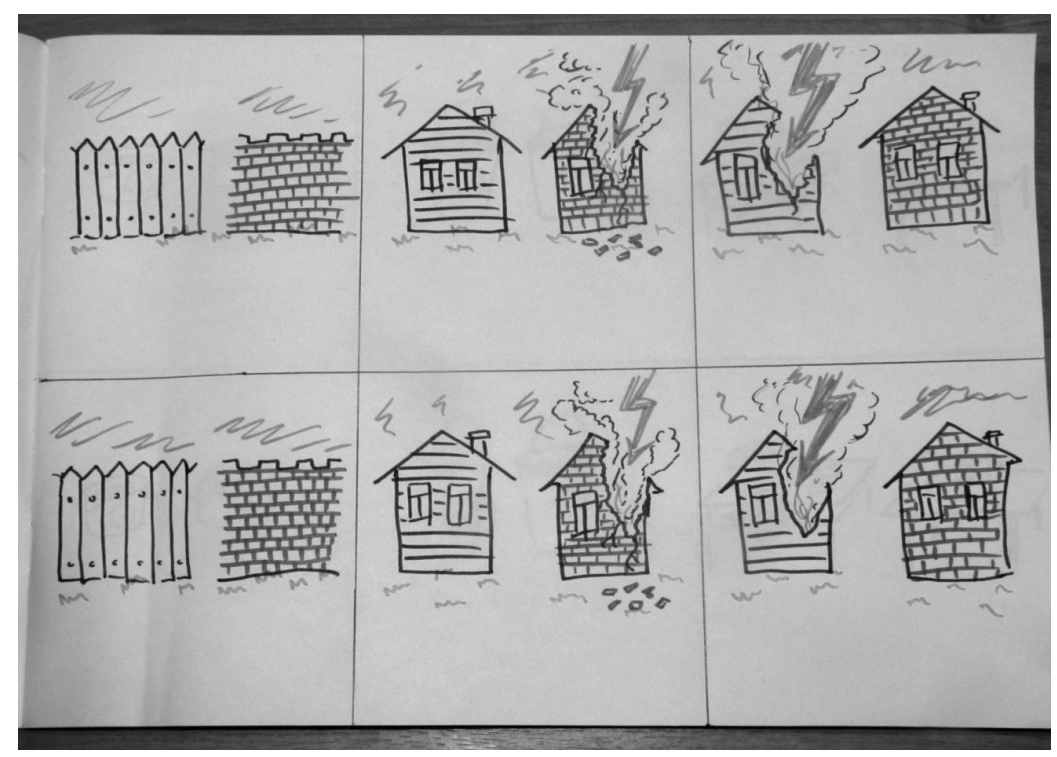

Figure 2. The cards for the 2016 experiment

This series of experiments was successful: we got more than 15 examples on case compounding in DO-position and also several examples for other positions.

In 2015, we also ran a series of experiments of the "maze" type. During this type, the Director and the Matcher become identical threedimensional models and identical sets of three-dimensional figures. The models we used represented the area of a village where the experiment took place. It helped speakers to associate the model with their place of living. During the experiment, the Director was looking at figures one of us was moving in front of them through the landscape model (maze) and was trying to describe the trajectory to the Matcher. The task of the Matcher was to repeat the movements of figures on the identical landscape model as precisely as possible. Figures were partly toys (five 
wooden puppets and five cars), partly hand-made of play-dough (two bags, three loafs of bread, three boxes of sugar). Fig. 3 shows one of the participants with a model of Shamardan area and with all figures used during the "maze" type of experiments:

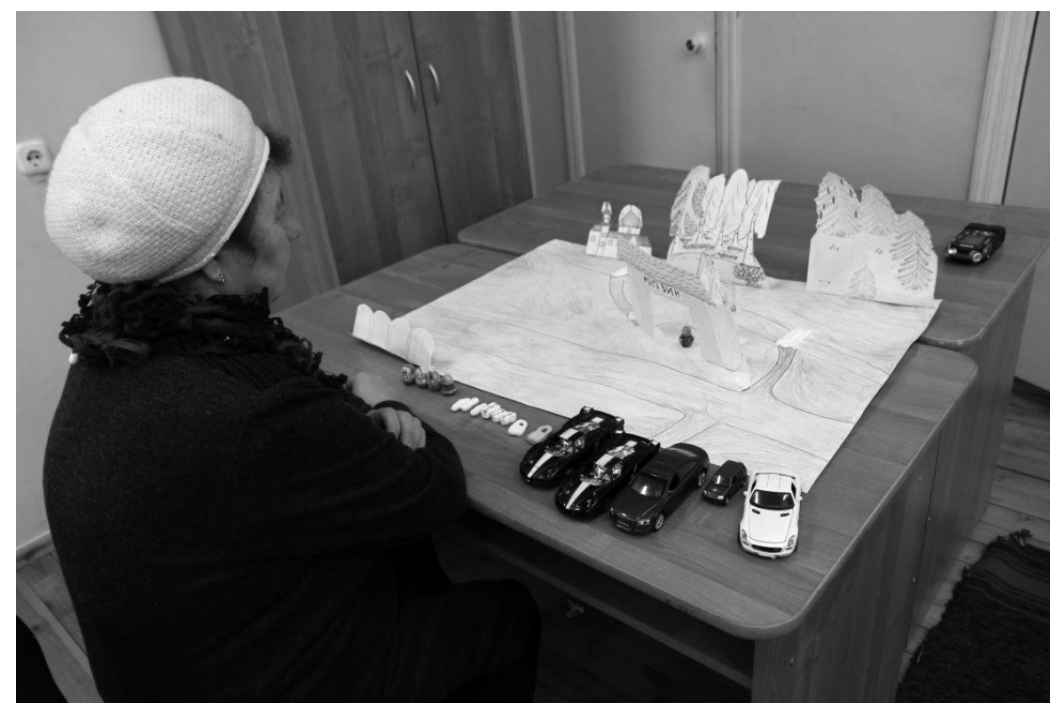

Figure 3. The setting of the 3-dimensional "maze" experiment

\subsection{Topicality and contrast}

The experiments were designed in such a way that the same figures appeared repeatedly in different contexts, they could be focal or topical, activated or not activated. Most figures came also in pairs or small sets, inside which they differed in one parameter, e.g. hair color of otherwise identical girls or the side from which the cars came, which enabled contrastive contexts. The figures also occupied different positions on the animacy hierarchy, but this parameter did not prove to be relevant.

It looks like relative accessibility of the head (compared to its dependent), in terms of Slioussar (2009: 52-57), is the most important factor predicting the appearance of the case marker on the dependent: the less accessible/topical the dependent compared to the head, the greater the probability of it being marked. If the dependent is a noun in one of the adnominal cases, this leads to case compounding. However this rule does not discriminate between this and other kinds of adnominal modifiers. Adjectives, which normally do not inflect for case and have a 
dedicated adjective plural suffix -es', also copy the case and the nominal plural marker -os/-jos (if there is one) from their heads under those conditions (12), (13). This concerns non-derived adjectives as well as those derived from nouns with the help of one of the attributivizers.

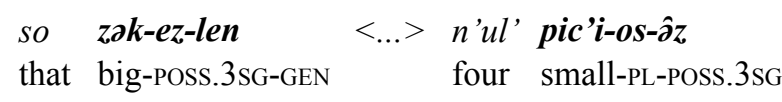

'That big one [girl] <... has four small ones [candies].' (B)
(13)
so kanfet-jos-se zok-jos-se s'ot-i-z
$\mathrm{s} /$ he candy-PL-Poss.3SG.ACC big-PL-Poss.3SG.ACC give-PST-3SG
'She gave [him] big candies.' (B)

In both these examples the object denoted by the head (candies in both cases and also the girl in the first case) have already appeared several times in speech in the close vicinity of these utterances, and are therefore well activated and highly topical. The attributes of these objects (their size in both examples) are, on the other hand, much more focal, which typically occurs in contrastive contexts. The head, which is due to its topicality not important for the conversation and is off screen in terms of Padučeva (2004: 58-59), can therefore be omitted, as in (12). Even when it is not, as in (13), it is either located to the left of its dependent or separated from it with special intonation. Special intonational patterns, movement to the left or omission are features crosslinguistically typical for topical items. Each of these processes, however, would make it more difficult for the listener to recover the syntactic structure of the utterance in Beserman, and in the latter case, also to reconstruct the omitted head. Copying the case and number markers from the head makes reconstructing the relation between the head and the dependent, regardless of their mutual position, much easier. It also indicates the syntactic position of the head, should it be omitted, and therefore helps the listener to reconstruct it. The case compounding phenomenon, which we always met under such circumstances, is therefore a by-product of this topicalization-induced case copying.

\subsection{The obligatoriness of Poss.3sG}

As discussed previously, the second case in compounding is said to obligatorily come with a POss.3sG marker. This is paralleled by Moksha, 
where the outer case can only belong to the definite declension. Indeed, the speakers who we asked usually refused to accept otherwise correct sentences with case compounding when the POss.3sG marker did not accompany the outer case. It turned out, however, that it is in fact not required by the case compounding construction per se, even when the inner case is adnominal and the outer case is copied from the elided head. The transcriptions of our experiments contain several contexts where no possessive marker is present (14), (15), which proves this point.

$$
\begin{array}{llll}
\text { lâz, lâz šapka-en-len tože! korz'inka-en } & \text { so. } \\
\text { blue blue hat-INS-GEN } & \text { also basket-INS } & \text { s/he }
\end{array}
$$

'The blue, the blue-headed one (girl) as well [has a basket]! She is with a basket.' (B)
(15) ben, vož kâšet-en-len pun-i kal' mon
yes green headscarf-INS-GEN put-PST.1sG now I.NOM
'Yes, I've just put [the hedgehog] by the one (old lady) with green head- scarf.' (B)

Just as in other examples with headless case-compounding, the head in both examples is highly topical, since the speakers have discussed the figures of girls or ladies for a long time already. What makes them different from most other contexts in our corpus is that the attributes (blue hat and green headscarf, respectively), although less topical, are still not the main point of concern for the speaker. Both blue-hatted girl and green-headscarved lady are not compared with their differently clothed counterparts in these sentences. In (14), the Director wants to make sure the Matcher places a basket in the hands of the blue-hatted girl as well, just as she did it with other girls. In (15), the Matcher draws the Director's attention to the fact that she has already put a hedgehog next to the lady and would like to ask for further directions. In both examples, the whole noun phrase is in topic, and there is either no or only very mild contrast.

The POSs.3sG in Udmurt is different from other possessive markers because it has developed a number of non-possessive functions (Lytkin et al. 1974, Perevoščikov 1962: 84-85, Winkler 2001: 29, Kuznecova 2012, Tánczos 2016). It is also structurally outstanding: while adnominal dependents can copy the case and the number markers from the head, they cannot copy the possessiveness markers. Only the POss.3sG marker 
can appear on adjectives in this setting and accompany the outer case in nouns with case compounding, even if the head is marked with another possessive suffix. This peculiarity is the reason why POss.3sG in such contexts is sometimes treated as a nominalizer or a separate category that enables an adnominal form to acquire nominal morphology.

One of the contexts where POss.3sG in this non-possessive function is used, is contrastive topic. Whenever an object is topical, but is contrastively compared or opposed to another topical object, it is marked with this suffix. When the contrast involves the entire NP, POss.3sg attaches to its head, as in (16).

$\begin{array}{llll}\text { ton } & \text { vaj } & \text { butill'-ze } & \text { kel }^{\prime} t-\hat{\partial}, \\ \text { you(SG).NOM } & \text { let's } & \text { bottle-POSS.3sG.ACC } & \text { leave-IMP.SG }\end{array}$

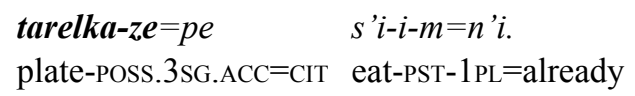

'Let the bottle stay, and let's say we've eaten the plate.' (B)

In this example, the Director gives the Matcher the instructions: the card with a bottle should stay on the table, and the one with a plate should be discarded. The bottle and the plate are both topical, but they are contrastively compared and therefore marked with POSs.3sG. It is also instructive that the word pal 'side', which normally implies contrast between the two sides, is predominantly used with the POss.3sG marker (179 out of 231 cases, or $77 \%$, for locative and illative, which are most frequently used with this word).

When only the dependent, but not the head, is in the scope of contrast, the dependent gets this suffix. It follows that the factors that trigger the appearance of POss.3sG in this function are the same as the ones governing adnominal case compounding or copying the head morphology to a dependent adjective. It comes as no surprise then, that case compounding and Poss.3sg marking go hand in hand so often. Nevertheless, the examples (14) and (15) with reduced contrast and no POSs.3SG on the one hand, and (16), where POSs.3sG is used for the same purpose without case compounding, prove that these are at least partially independent processes, and one does not necessarily require the other. Therefore, even if one treats this kind of POSs.3sG as a separate category, we believe it is incorrect to analyze it as a nominalizing device. 


\section{Peripheral case compounding kind}

Finally, let us first consider those kinds of case compounding that are infrequent and play only a peripheral role in the grammar. The constraints on these kinds and the factors triggering their appearance in speech differ from those relevant for the more frequent kinds covered above.

\subsection{Derivational compounding}

The derivational compounding is the most marginal of the three. Normally, case markers in Udmurt attach to the bare stem and do not require that it be modified with any other suffix before that. However, the recessive case (recall example (3)), which does not exist in the literary language, has not yet fully grammaticalized (Usacheva and Arkhangelskiy 2017). One of the signs of its incomplete grammaticalization is the fact that some speakers allow it to attach to the genitive marker, rather than attaching it directly to the stem (17):
a. mužik-las'en
b. mužik-len-las'en
husband-RCS
husband-GEN-RCS
'[wedding guests] from the side of the husband' (E)

Both words have exactly the same meaning, however, in (17b), the recessive marker uses the stem with the genitive as an oblique stem of sorts. This is probably a remnant of the stage when the recessive marker was an adposition and could take a noun in either the nominative or the genitive as its dependent. The compounded form is clearly marginal: it is not unanimously approved by the speakers and does not show up in texts. Another nominal case that, even less frequently, can occasionally allow such kind of compounding in Beserman, is the approximative (-lan'), which is semantically the opposite of the recessive. Since there is no recessive in literary Udmurt, and the approximative is all but dead, it is safe to say that derivational compounding does not exist in the standard language. 


\subsection{Case stacking}

Case stacking resulting from combination of several spatial case affixes (denoting e.g. localization and orientation) can be found in multiple Komi varieties (Baker 1985: 225-240, Kuznecov 2012: 165), which are closely related to Udmurt, and took place in earlier stages of Komi and Udmurt, giving rise to a number of contemporary case markers (Tauli 1956). In literary Udmurt, combinations of the marker -lan' with spatial cases (normally locative or illative) have the deceiving appearance of case compounding. However, our corpus data reveals that this suffix, described in the grammars as the approximative case marker, is actually used only as a derivational suffix that can modify a very limited number of stems. Therefore, these combinations in literary Udmurt cannot be viewed as true instances of case stacking. In Beserman, where the approximative is a productive and relatively frequently used case, such combinations are hardly ever used. Out of 187 occurrences of the approximative in our Beserman corpus, none were combined with other spatial cases. The only relevant elicited example that we have (18) was accepted only by some speakers, who nevertheless indicated the variant without compounding as preferable.

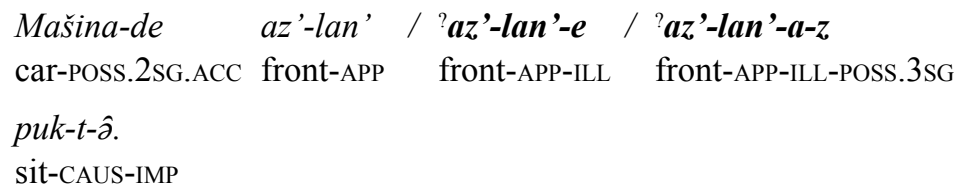

Since $a z^{\prime} l a n$ ' is by far the most frequent literary Udmurt word with the approximative marker to be used with the illative and locative markers, and the Beserman speakers are familiar with the literary language, the appearance of $a z$ 'lan'e in Beserman could be explained by the influence of the standard variety.

We are not aware of any other spatial case stacking instances within one noun in Beserman or literary Udmurt ${ }^{3}$. However, there occur compounds where one of the cases is spatial (or temporal) and the other is not. One example is the combination of the approximative with the

3 There are pronominal forms with case stacking, such as $k \hat{\partial} t-\hat{\partial} n-a-z$ where-LOC-LOCPOSS.3SG 'where' or $t a-t$ ' $i-j a-z$ here-PROL-LOC-POSs.3SG 'here', but this goes beyond the scope of the present paper. 
3sG possessive accusative marker (19), which exists in both varieties. It happens rarely in Beserman (three occurrences out of 187), but unlike the previous one, it seems to be perfectly grammatical.

$$
\text { Mar, l'uka-zh=no } \quad n u-i-z \hat{\partial}=n ' i \quad \text { ber-lan'-ze. }
$$

what gather-PST.3PL $=$ ADD drive-PST-3PL=already back-APP-POSS. $3 \mathrm{sG} . \mathrm{ACC}$

'So they gathered [us] and drove [us] back.' (B)

As we discussed earlier, the POss.3sg in Beserman is known to have a range of non-possessive functions, including reactivation of a previously mentioned, but partly forgotten object. The choice of the accusative case in this context is not completely clear to us. In some of the Komi varieties, the $3 \mathrm{sg}$ and $2 \mathrm{sg}$ possessive accusative markers were degrammaticalized into a kind of a focus particle (Klumpp 2014: 438) that can stick to e.g. adverbs and infinitives. It can be that the Udmurt Poss.3sG. ACC marker is in the beginning of the same path. We attested multiple instances when it was used with adverbs, both in Beserman and literary Udmurt. However we do not know how widespread this phenomenon is and what are the factors triggering it. We can also note that the only two words that we have seen to contain this particular combination of affixes, are berlan' 'backwards' and az'lan' 'ahead', and they could be conceptualized as adverbs by the speakers. Therefore, their analysis as case stacking instances is also dubious.

Finally, the only full-fledged case stacking pattern in literary Udmurt comes from the combination of the dative with the terminative (and perhaps other cases, on which we unfortunately do not have any data). The dative here can express purpose, or mean 'for' in the temporal sense, while the terminative has the temporal meaning 'up to'. Their combination yields the meaning 'for up to' in a straightforward fashion, as shown by the example (20). We do not know yet whether the same applies to the Beserman dialect, but this seems not impossible.

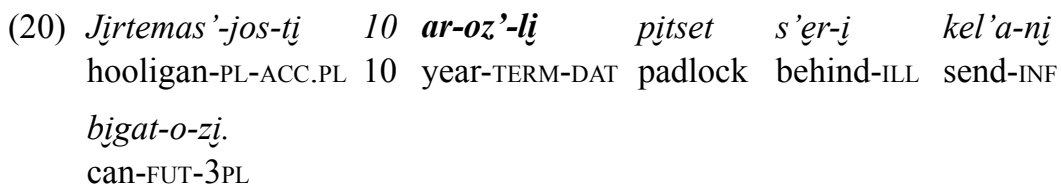


It should be noted however, that the dative is different from other cases in that it is sometimes used as a derivational, rather than inflectional, suffix. Namely, it can attach to some temporal adverbs to produce other temporal adverbs, e.g. Beserman kama 'long (in a temporal sense)' $\rightarrow$ kamalâ 'for a long time'.

\subsection{Case compounding in a coordinating construction}

Coordinating case compounding happens when one of the cases is required by a coordinating construction, and the other originates elsewhere, as in (22). In one of several Beserman coordinating constructions, both coordinated nouns are marked with the instrumental suffix (which also has comitative meaning). When these nouns should also be marked with another case, this leads to a collision. It seems that generally such situations are avoided by the speakers, who choose another coordinating construction that does not require additional case marking. 37 out of 55 occurrences of coordinating instrumental in our corpus are subjects, and 13 further occurrences are dependents of the relational noun vis 'between', which also does not require any case marking.

When the speakers do use this construction, two strategies could be employed. One option is to replace one of the coordinating case markers with the other required case, as in the first coordinand in (21). Note that the plural possessive marker on 'belly' indicates that it is possessed by both animals rather than by the bear alone. The fact that the speaker first pronounces the coordinating construction with two instrumentals and then corrects herself, as if though she tried, but could not find a place for the genitive marker, is also telling.

(21) J'ic'â vel't-ic'oz' gondâr-en kijon-en ... gondâr-len kijon-en fox wander-LIM bear-INS wolf-INS bear-GEN wolf-INS

kat-sâ s'uma-z

belly-POSS.3PL feel.hungry-PST.3SG

'While the fox was wandering around, the bear and the wolf got hungry (lit. the belly of the bear and the wolf started feeling hungry).' (B) 
The other strategy is to suspend the case suffix and attach it to the whole coordinated phrase, as in (22), which leads to case compounding.
[abi-jen
babam-en]-jos-len ta korka-jez
[grandmother-INS
grandfather-INS]-PL-GEN this house-POss.3SG

'This house belongs to my grandmother and grandfather.' (B)

\section{Conclusions}

Beserman and Literary Udmurt have numerous kinds of case compounding. Peripheral kinds include case stacking, derivational case compounding and case compounding in coordinating constructions (we attested the latter two only in Beserman). The most frequent and productive kinds of compounding, however, are adnominal (headed or headless) and, to a lesser extent, complex attributive nominal. It seems that the main morphological constraint on the inner case is that the form marked with it should be able to be used adnominally. While prototypically adnominal cases (the genitives and the instrumental) always allow case compounding, others can also become adnominal in certain contexts, where they also allow case compounding. It is not entirely clear whether this restriction is absolute, as we attested a handful of examples where the word form with the inner case seemed to be an adjunct rather than a nominal dependent. In all such cases, the verb whose adjunct this word used to be, was omitted, but easily and uniquely reconstructible. The constraint on the first case is definitely lifted under comparative deletion, where the elided part of the sentence is also uniquely reconstructible. We found no constraints on the outer case. There also seem to be no hard restrictions on the affix chain length, however, nominal forms with more than two case markers did not appear in any of our corpora.

Our experimental data shows that adnominal case compounding occurs in speech when the object expressed by the head of the NP is topical and not important, but its attribute expressed by its dependent, is important, which usually happens in contrastive contexts. The POss.3sG marker normally accompanies the outer case in such forms. However, we found out that it is not always obligatory in adnominal case compounding, at least in Beserman. We argue that the reason why it, nevertheless, appears so often in case compounding, is that the factors that cause case compounding are the same that cause the appearance of 
POSS.3SG in this sense. These two processes are not interconnected, and therefore the analysis of POSS.3SG as a nominalizer is inappropriate.

\title{
Acknowledgements
}

The work was supported by RSCF grant 18-18-00462 “Communicative-syntactic interface: typology and grammar". The corresponding project is realized in The Pushkin State Russian Language Institute.

\author{
Addresses \\ Timofey Arkhangelskiy \\ Peter-Timm-Str. 26 \\ D-22457 Hamburg \\ Germany \\ Maria Usacheva \\ Lyuby Novoselovoy street 18-247 \\ 143003 Odintsovo \\ Russia
}

\section{References}

Alatyrev, Vasily I. (1983) “Kratkij grammatičeskij očerk udmurtskogo jazyka”. [A short grammar sketch of Udmurt.] In A.S. Belov, V.M. Vakhrushev, N.A. Skobelev, and T.I. Tepljašina, eds. Udmurtsko-russkij slovar', 561-591. [Udmurt-Russian dictionary.] Moskva: Russkij jazyk.

Baker, Robin (1985) The development of the Komi case system: a dialectological investigation. (Mémoires de la Société Finno-Ougrienne Helsinki, 189.) Helsinki: SUS.

Bubrikh, Dmitry V. (1949) Grammatika literaturnogo komi jazyka. [Grammar of literary Komi Zyrian.] Leningrad: LGU im. A.A. Ždanova.

Clark, Herbert H. and Deanna Wilkes-Gibbs (1986) "Referring as a collaborative process". Cognition 22, 1-39.

Dench, Alan and Nicholas Evans (1988) "Multiple case-marking in Australian languages". Australian Journal of Linguistics 8, 1-47.

Girbau, Dolors (2001) "Children's referential communication failure: the ambiguity and abbreviation message". Journal of Language and SocialPsychology 20, 81-89. 
Hamari, Arja (2015) "Genitive and the secondary declension of the Mordvin languages - a syntactic perspective". Presentation at XII International Congress for Finno-Ugric Studies. Finland, Oulu.

Hamari, Arja (2016) "The genitive in the secondary declension in the Mordvin languages". Finnisch-Ugrische Mitteilungen 40, 1-33.

Judina, Maria V., and Olga V. Fedorova (2009) "Razrešenie sintaksičeskoj neodnoznačnosti: effekty prajminga i samoprajminga". [Resolving of syntactic ambiguity: priming and self-priming effects.] In Aleksandr Je. Kibrik et al., eds. Kompjuternaja lingvistika i intellektual'nye texnologii: po materialam ežegodnoj Meždunarodnoj konferencii "Dialog 2009" (Bekasovo, May 27-31, 2009), 554-558. Moskva: RGGU.

Klumpp, Gerson (2014) "Identifiability, givenness and zero-marked referential objects in Komi”. Linguistics 52:2, 415-444.

Kozlov, Alexey, Polina Pleshak, and Maria Privizentseva (2016) "Case compounding and discourse structure in Moksha". Paper at the workshop "Information Structure and Discourse in the Minority Languages of the Russian Federation", London, December 2-3 2016.

Krauss, Robert M. and S. Weinheimer (1966) "concurrent feedback, confirmation and the encoding of referents in verbal communication". Journal of Personality and Social Psychology 4, 343-346.

Kuznecov, Nikolaj (2012) Prostranstvennaja semantika mestnyx padežej komi jazyka (kognitivnyj analiz). (Dissertationes philologiae uralicae Universitatis Tartuensis, 12.) Tartu: Tartu Ülikooli Kirjastus.

Kuznecova, Ariadna I. (2012) "Kumuljacija grammatičeskix značenij v aggljutinativnyx pokazateljax: dejktičeskie funkcii posessiva $\mathrm{v}$ ural'skix jazykax". [Cumulation of grammatical meanings in agglutinative markers: deictic functions of possessive suffixes in Uralic languages.] In Ariadna I. Kuznecova, ed. Finno-ugorskie jazyki: fragmenty grammatičeskogo opisanija. Moskva: Jazyki slavjanskix kul'tur.

Ljukina, Nadežda M. (2008) Osobennosti jazyka balezinskix i jukamenskix besermjan. [Peculiarities of the language of Balezino and Jukamenskoje Besermans.] Unpublished doctoral dissertation. Iževsk: Udmurt State University.

Lytkin, Vasilij I., Klara E. Majtinskaja, and Károly Rédei, eds. (1974) Osnovy finno-ugorskogo jazykoznanija (voprosy proisxoždenija i razvitija finnougorskix jazykov). [Foundations of Finno-Ugric linguistics (issues on genesis and development of Finno-Ugric languages).] Moskva: Nauka.

Noonan, Michael (2008) "Case compounding in the Bodic languages". In Greville Corbett and Michael Noonan, eds. Case and grammatical relations, 127-147. Amsterdam: John Benjamins.

O’Neill, Daniela K. (1996) "Two-year-old children's sensitivity to a parent's knowledge state when making requests". Child Development 6, 659-677.

Padučeva, Elena V. (2004) Dinamičeskie modeli v semantike leksiki. [Dynamic models in lexical semantics.] Moskva: Jazyki slavjanskoj kul'tury. 
Pan, Barbara A. and Catherine E. Snow (1999) "The development of conversational and discourse skills". In Martyn Barret, ed. The development of language, 229-250. London: Psychology Press.

Perevoščikov, Petr N. (1962) Grammatika sovremennogo udmurtskogo jazyka. Fonetika i morfologija. [Grammar of modern Udmurt. Phonetics and morphology.] Iževsk: Udmurtskoe knižnoe izdatel'stvo.

Plank, Frans, ed. (1995) Double case: agreement by Suffixaufnahme. Oxford: OUP.

Privizenceva, Maria (2015) “Dvojnoe padežnoe markirovanie v mokšanskom”. [Case compounding in Moksha.] Paper presented at XII conference on typology and grammar for young researchers, St. Petersburg, 19.11.2015.

Slioussar, Natalia (2009) Na styke teorij: grammatika i informacionnaja struktura $v$ russkom i drugix jazykax. [On the crossroads of theories: grammar and information structure in Russian and other languages.] Moskva: Editorial URSS.

Stassen, Leon (1985) Comparison and universal grammar. Oxford: Blackwell. Tánczos, Orsolya (2016) "Towards a unified account of the suffix -ez/jez in Udmurt". Talk at SLE 2016.

Tauli, Valter (1956) “The origin of affixes". Finnisch-Ugrische Forschungen $32,2,170-225$.

Tepljašina, Tamara I. (1970) Jazyk besermjan. [The language of the Beserman.] Moskva: Nauka.

Usacheva, Maria and Timofey Arkhangelskiy (2017) "Grammaticalization of new cases in Beserman Udmurt”. Linguistica Uralica 53:1, 27-48.

Winkler, Eberhard (2001) Udmurt. (Languages of the world / Materials, 212.) München: Lincom Europa.

Xolodilova, Maria (2015) “Sravnitel'nye konstrukcii i ierarxija dostupnosti imennyx grupp v besermjanskom udmurtskom i mokšanskom”. [Comparative constructions and the accessibility hierarchy in Beserman Udmurt and Moksha.] Paper presented at XII conference on typology and grammar for young researchers, Saint Petersburg, 19.11.2015.

Yule, George (1997) Referential communication tasks. Mahwah/NJ: Erlbaum. Zajceva, Galina L. (2000) Žestovaja reč'. Daktilologija. [Gesture speech: dactilology.] Moskva: Gumanitarnyj izdatel'skij centr "Vlados".

\section{Аннотация. Тимофей Архангельский и Мария Усачева: Множествен- ное падежное маркирование в бесермянском диалекте удмуртского. Объектом нашего исследования является множественное падежное мар- кирование, т. е. наличие нескольких падежных показателей внутри одной словоформы, в бесермянском диалекте удмуртского, который мы также кратко сравниваем с литературным удмуртским. В этом идиоме засви- детельствованы почти все типы множественного маркирования согласно типологии Нунана (Noonan 2008), хотя деривационный тип и отложенная}


аффиксация явно маргинальны. Для изучения ограничений на это явление мы используем эксперименты на референциальную коммуникацию и корпусные данные. Мы также демонстрируем, что посессивное маркирование, которое часто считается обязательным в такой ситуации (см., напр., Алатырев 1983: 586, Winkler 2001: 43), на самом деле появляется благодаря тем же информационно-структурным факторам, что и множественное маркирование, а не вызывается непосредственно последним. Статья в основном основана на данных, собранных авторами в поле в 2003-2017 гг.

Ключевые слова: удмуртский язык, бесермянский диалект, множественное падежное маркирование, информационная структура

Kokkuvõte. Timofey Arkhangelskiy ja Maria Usacheva: Käänete liitmine Bessermani udmurdi keeles. Artiklis uuritakse käänete liitmist, s.t noomenitüvele mitme käändelõpu lisamist Bessermani udmurdi keeles, võrreldes seda ka udmurdi kirjakeelega. Pea kõik käänete liitmise tüübid on Noonani (2008) kirjelduste järgi keeles kasutusel, kuigi tuletuslikul ja katkestatud lisamisega liitmisel on väike osatähtsus. Kasutame viitelise suhtluse eksperimente ja korpusandmestikku, et selle nähtuse piire analüüsida. Samuti väidame, et possessiivne märkimine, mida peetakse liitmisel sageli kohustuslikuks (nt Alatyrev 1983: 586, Winkler 2001: 43), ei tulene niivõrd mitte liitmisest endast, vaid informatsioonilis-struktuurilistest faktoritest, mis on liitmisega seotud. Artikkel põhineb peamiselt andmetel, mille oleme teema kohta kogunud aastatel 2003-2017.

Märksõnad: udmurdi keel, Bessermani udmurdi keel, käänete liitmine, informatsiooniline struktuur 


\section{Appendix 1. Standard Udmurt and Beserman cases systems ${ }^{4}$}

\begin{tabular}{|c|c|c|c|}
\hline Case & Gloss & Standard Udmurt & Beserman \\
\hline nominative & NOM & $-\varnothing$ & $-\varnothing$ \\
\hline accusative & $\mathrm{ACC}$ & $-e z$ & $-e z$ \\
\hline genitive & GEN & -len & -len \\
\hline ablative / second genitive & ABL / GEN2 & -les' & -les' / -lâs' \\
\hline dative & DAT & $-l i$ & -lâ \\
\hline instrumental & INS & $-e n$ & $-e n$ \\
\hline caritive & CAR & -tek & -tek \\
\hline adverbial & ADV & $-j a$ & $-j a$ (very rare) \\
\hline locative & LOC & $-i n$ & $-\hat{n} n$ \\
\hline illative & ILL & $-e$ & $-e$ \\
\hline elative & ELA & $-i s s^{\prime}$ & $-\hat{\partial} s^{\prime}$ \\
\hline egressive & EGR & -is'en & -is'en \\
\hline terminative & TERM & $-O z^{\prime}$ & $-O z^{\prime}$ \\
\hline prolative & PROL & $-t i /-e t i$ & $-t^{\prime} i$ \\
\hline approximative & APP & does not exist & -lan' \\
\hline recessive & RCS & does not exist & -las'en \\
\hline $\begin{array}{l}\text { series of personal-local } \\
\text { cases ('at someone's } \\
\text { place') }\end{array}$ & DMS & do not exist & $\begin{array}{l}-n^{\prime}-+ \text { one of } \\
\text { the local cases }\end{array}$ \\
\hline
\end{tabular}

4 Only the main allomorphs that precede the possessiveness markers and productively attach to nominal stems that end in a consonant, are given. 